\title{
Virtual Pedodontics Library
}

\author{
It is mandatory that new teaching and learning methods are \\ adopted so as to adapt education to current reality.
}

\author{
Sandra Kalil Bussadori*, Patricia Eberson da Silva**, Antonio Carlos Guedes-Pinto*** \\ * PhD, Chair Professor, Department of Dental Materials, School of \\ Dentistry, Metropolitan University of Santos, Brazil. \\ ** Specialization in Pediatric Dentistry. \\ *** PhD, Chair Professor, Department of Orthodontics and Pediatric \\ Dentistry, School of Dentistry, University of São Paulo, Brazil.
}

\section{ABSTRACT}

In this research, a CD-ROM on pediatric dentistry was developed, culminating in the first volume of the Pedodontics Virtual Library. Once the CDROM was ready, a questionnaire was applied to 30 interviewees, comprising professors, undergraduate and graduate students, in order to evaluate teaching and learning methods. The questions about the CD-ROM concerned the format of the program, the clarity of the presented techniques, the ease of use and the value of the CD-ROM as a didactic method. The questionnaire assessed personal characteristics of the interviewees as well. The answers were descriptively analyzed by means of tables of frequency and Fisher's exact test. After the results were evaluated, it was possible to conclude that the most utilized didactic methods in class were slides and blackboards, while the utilization of CD-ROM was uncommon, for both teachers and students. Most of the interviewees utilize the Internet, and very few have experienced distance education. The program is very clear as to the presented techniques and their indications. The subjects considered the CD-ROM a good didactic method and showed interest in learning how to use it. It is possible to conclude that the CD-ROM interested the interviewees, who found it useful as a teaching and learning method.

\section{DESCRIPTORS}

CD-ROM. Pediatric dentistry. Libraries.

nformation technology has played an undeniably important role in various educational and leisure areas. Nowadays, the computer is present earlier in an individual's life. The importance of information technology in the search for information is unquestionable, due to the ease and efficiency of the method. The resulting dependence of users is evident as well.

Computers have been traditionally thought of as mere instruments for quick transmission of information. Nevertheless, their potential exceeds this reduced concept, which allows them to be considered a new type of social product. One can think of them as "intelligent products", which means that they are capable of altering relations between people.

In current society, in which the individual is surrounded by information technology, the computer is not merely a consumer good. It represents a vision of reality that enables the user to interact with situations and techniques that he sometimes has difficulty in understanding or visualizing by means of traditional teaching-learning methods.

Capitalism has created a new model of notorious knowledge, in which technology assumes increasing dynamism. Considering the history of human knowledge, contemporary science has radically altered previous knowledge paradigms.

TOFFLER, TOFFLER (1997), in their book, A terceira onda (The third wave), describe three successive waves in human civilization. The first appeared at the beginning of time and persisted until the end of the $18^{\text {th }}$ century. In that period, society was essentially agricultural. The second wave occurred after the $18^{\text {th }}$ century and was characterized by considerable industrial development. Currently, the third wave of civilization is based, mainly, on the fact that products are customized and designed for interactive utilization.

In the third wave everything changed. With the 
creation of the worldwide net (or web) of computers, the Internet, learning how to manage general information was no longer enough. It became necessary to deepen it, decoding information in all its complexity. That is because now the user faces the process of transmission and production/reproduction of information alone.

Considering those facts, one cannot deny the progress of the aforementioned process. It is mandatory that new teaching and learning methods are adopted so as to adapt education to current reality. The background of students has also changed, and university professors must keep up with such changes. This fact directly affects university departments - up-to-date knowledge is now a strategic asset.

Since professors and students have to constantly recycle, interactive methods for teaching and learning will certainly be useful, enabling better visualization of the proposed techniques.

CARVALHO JR, SABBATINI (1999) state that multimedia is the integration of various methods of information - sounds, images and texts - in the computer. It corresponds, in information technology, to what is known as "multimeans" in art and pedagogy, with the advantage of interactivity, i.e., the possibility of commanding the access to information in multiple ways, such as by dialog.

It is important to point out - so that the learning process occurs satisfactorily - that professors must be sensitive to incorporate this new reality. In essence, the teaching and learning process is demanding, and only after a certain time one can safely evaluate the stage achieved in personal and professional developments.

In a study carried out in the United States, in the "1997 Campus Computing Survey" it was observed that, in spite of the investments of colleges and universities in hardware and software, one of the greatest challenges faced by the country is to lead all faculty to integrate technology and teaching, using information technology as an instrument to facilitate learning in both research and courses. However, one must consider that it is more difficult to train teachers whose professional education was traditional, with no access to such tools.

The objective of the present research was to develop a CD-ROM on pedodontics, resulting in the first volume of the Pedodontics Virtual Library. The techniques are presented in detail, with all their clinical steps, which allows learning in a clear and consistent way and contributes to the development of the proper tools for efficient teaching by means of the computer.

\section{MATERIAL AND METHODS}

The present research consisted of two stages: the development of the CD-ROM and its evaluation by selected subjects.

\section{Content of the CD-ROM}

To create the CD-ROM, the authors prepared a script with the clinical steps of techniques for the restoration of posterior teeth as advocated by the Center for Research in Pediatric Dentistry, Areas of Restorative Dentistry and Dental Materials, School of Dentistry, University of São Paulo.

\section{Navigation of the CD-ROM}

Based on the script, the navigation system of the CD-ROM was designed so as to display the steps of the restorative techniques on the screen in an orderly fashion.

A specific questionnaire was developed to evaluate the proposed method for teaching and learning. The questionnaire was applied to professors, graduate and undergraduate students, in order to assess the ease of use and the adaptation of professors to this system.

\section{Methodology}

Thirty interviewees were selected among professors and students to answer the questionnaire composed of seventeen questions on the program's format (layout, links, etc.), clarity of the presented techniques, ease of use, value as a didactic method, and on the personal characteristics of the subjects. The thirty participants were divided into two large groups, for posterior analysis: undergraduate and graduate professors; undergraduate and graduate students; professors who were also attending gaduate courses were assigned to the professors' group.

For the analysis of answers, the questionnaires were divided according to assessed matters (in brackets, the number of each question):

- Classification of the sample: qualification [1], presentation of classes [2], utilization of CD-ROM in class [3], computerized searches [4].

- Program alterations: layout [5], links [6], images [7], texts [13].

- Clarity: presentation of techniques [9], explanatory CD-ROM [14].

- Didactic method: better understanding [10], 
Table 1 - Distribution of the subjects who answered the questionnaire.

\begin{tabular}{|c|c|c|c|}
\hline & & $\mathbf{n}$ & $\%$ \\
\hline \multirow{5}{*}{ Students } & Specialization & 5 & 16.7 \\
\hline & Internship & 1 & 3.3 \\
\hline & Extension courses & 3 & 6.7 \\
\hline & Undergraduate & 1 & 3.3 \\
\hline & Master's degree & 2 & 6.7 \\
\hline \multicolumn{2}{|c|}{ Total of students } & 11 & 36.7 \\
\hline \multirow{3}{*}{ Professors } & Undergraduate & 12 & 40.0 \\
\hline & Graduate & 1 & 3.3 \\
\hline & $\begin{array}{l}\text { Undergraduate and } \\
\text { Graduate }\end{array}$ & 6 & 20.0 \\
\hline \multicolumn{2}{|c|}{ Total of professors } & 19 & 63.3 \\
\hline \multicolumn{2}{|c|}{ Total of subjects } & 30 & 100.0 \\
\hline
\end{tabular}

adoption as a method [11], helps learning [15], more resources [16].

- Creating a CD-ROM: would like to learn how to create a CD-ROM [12].

\section{RESULTS}

\section{Classification of the sample}

Thirty questionnaires were applied: nineteen were answered by professors and eleven, by students. In Table 1, the distribution of participants is shown. For the classification of the sample, questions 1, 2, 3 and 4 were taken into account.

One can infer, by observing the data presented in Table 2, that few subjects taught and/or attended courses in which CD-ROM was utilized. The most commonly employed didactic resource usually are slides (mentioned by $83 \%$ of the interviewees). The quantity of blackboard users was very small (only one case).

In the analysis of question 3, which asked whether the interviewees had taught or attended classes with CD-ROM, one can observe (Table 3) that the number of interviewees who answered affirmatively was small ( $13 \%$ of the total).

Statistical comparison between the answers of students and professors by means of Fisher's exact test indicated that the utilization of CD-ROM was proportional in both groups (descriptive level of $0.685)$.
Table 2 - Distribution of utilized didactic tools.

\begin{tabular}{|l|c|c|c|c|}
\hline & Blackboard & Slides & $\begin{array}{c}\text { Digital } \\
\text { projector }\end{array}$ & CD-ROM \\
\hline Students & 1 & 7 & 5 & 1 \\
\hline Professors & 13 & 18 & 6 & 3 \\
\hline Total & 14 & 25 & 11 & 4 \\
\hline Percentage & 46.7 & 83.3 & 36.7 & 13.3 \\
\hline
\end{tabular}

Table 3 - Comparison between teachers and students as to the utilization of CD-ROM in class.

\begin{tabular}{|l|l|r|r|}
\hline \multicolumn{1}{|c|}{} & & $\mathbf{n}$ & $\%$ \\
\hline \multirow{2}{*}{ Students } & No & 8 & 26.7 \\
\cline { 2 - 4 } & Yes & 3 & 10.0 \\
\hline \multirow{2}{*}{ Teachers } & No & 15 & 50.0 \\
\cline { 2 - 4 } & Yes & 4 & 13.3 \\
\hline Total & & 30 & 100.0 \\
\hline
\end{tabular}

The need for alterations in the program was assessed by means of questions 5, 6, 7 and 13, which asked about page presentation (layout), navigation system (links), images and text presentation, respectively.

Based on the analysis of Table 4, one can observe that the occurrence of answers suggesting alterations in layout and images was similar to that of answers suggesting alterations in links. Comparing the frequency of those answers and the percentage of suggestions as to text alterations, it is possible to notice that the latter was smaller.

\section{DISCUSSION}

The world has gone through intense progress. We have changed from an agricultural to an industrial society. According to TOFLER, TOFFLER (1997), current products are increasingly customized and designed for interactive consumption. This reflects on the evolution of the Internet, which is a worldwide net of computers. According to MRECH (1998), it is no longer enough to deal with general information; it is necessary to deepen it, decoding information in all its complexity.

It must be pointed out that, in the present research, when professors were asked about how they utilize the computer to update their knowledge, $96.7 \%$ of the interviewees reported using the Internet in their research; both students and profes- 
Table 4 - Distribution of suggested alterations.

\begin{tabular}{|c|c|c|c|c|c|c|c|c|c|}
\hline & \multicolumn{2}{|c|}{ Layout } & \multicolumn{2}{|c|}{ Links } & \multicolumn{2}{|c|}{ Images } & \multicolumn{2}{|c|}{ Texts } \\
\hline & & $\mathbf{n}$ & $\%$ & $n$ & $\%$ & $\mathbf{n}$ & $\%$ & n & $\%$ \\
\hline \multirow{2}{*}{ Students } & No & 8 & 26.7 & 9 & 30.0 & 8 & 26.7 & 8 & 26.7 \\
\hline & Yes & 3 & 10.0 & 2 & 6.7 & 3 & 10.0 & 3 & 10.0 \\
\hline \multirow{2}{*}{ Professors } & No & 17 & 56.7 & 15 & 50.0 & 17 & 56.7 & 13 & 43.3 \\
\hline & Yes & 2 & 6.7 & 4 & 13.3 & 2 & 6.7 & 6 & 20.0 \\
\hline Total & & 30 & 100.0 & 30 & 100.0 & 30 & 100.0 & 30 & 100.0 \\
\hline
\end{tabular}

Table 5 - Utilization of computers.

\begin{tabular}{|c|c|c|c|c|c|c|c|}
\hline & & \multicolumn{2}{|c|}{ Internet } & \multicolumn{2}{|c|}{ CD-ROM } & \multicolumn{2}{|c|}{ Distance education } \\
\hline & & $\mathbf{n}$ & $\%$ & $\mathbf{n}$ & $\%$ & $\mathbf{n}$ & $\%$ \\
\hline \multirow{2}{*}{ Students } & No & 0 & 0.0 & 6 & 20.0 & 10 & 33.3 \\
\hline & Yes & 11 & 36.7 & 5 & 16.7 & 1 & 3.3 \\
\hline \multirow{2}{*}{ Professors } & No & 1 & 3.3 & 11 & 36.7 & 17 & 56.7 \\
\hline & Yes & 18 & 60.0 & 8 & 26.7 & 2 & 6.7 \\
\hline \multicolumn{2}{|l|}{ Total } & 30 & 100.0 & 30 & 100.0 & 30 & 100.0 \\
\hline
\end{tabular}

sors search the Internet for up-to-date information (Table 5).

According to SETZER (1999), the Internet has brought innovations from the educational point of view, facilitating the exchange of information. This assertion is feasible. However, we agree with the author's statement that these innovations should be introduced in a gradual manner, since the amount of informative trash on the net is great, and, many times, it is difficult to find specifically what one is searching for. CHAVES, SETZER (2000) point out that, when people access the Internet as an alternative means for obtaining information, the result should not be presented in large, complex modules of information; it should be specific and presented in compact modules.

LÉVY (1993) states that universities currently offer professors and students more opportunity to navigate through the net and update by means of multimedia tools (CD-ROM, on-line multimedia interactive databases). In the comparison between students and professors, despite the lack of a statistically significant difference, students utilize the CD-ROM tool more frequently than professors. This is probably related to the fact that students have had more previous contact with multimedia resources in elementary and high schools.

A fact that called our attention was that all inter- viewees recognize the need for updating and training in information technology, even though the difficulty in adopting new teaching and learning techniques is instilled in some individuals.

Such difficulties were reported in a research carried out in the United States, in 1997. It was found that, in spite of the investments made by colleges and universities in software and hardware, the most complicated factor was the training of professors.

TAJRA (1998) points out that one of the primordial factors of this new didactic phase is the capacitation of professors. When didactic resources utilized by students and professors are assessed, slides (83\%) and the blackboard $(46.7 \%)$ are still the most common, as can be observed in Table 2. This fact indicates that there is some resistance in utilizing computerized resources, since only $23 \%$ of the subjects utilize the CD-ROM, and $37 \%$ use digital projectors in their presentations.

Regarding the CD-ROM, notwithstanding the fact that its utilization in class is not a habit, the interviewees reported that the method helped learning and enabled better understanding. All of the subjects were in favor of its adoption.

Internet sites on specific subjects have been an aid in obtaining information and access to published papers. Hence, one cannot be indifferent to their development. An important observation re- 
ported by LÉVY was that the production of multimedia is similar to the production of a show, requiring the work of a team of authors on a collective job. The author cites, as an example, the production of an Interactive Encyclopedia CD-ROM, which requires the work of professionals from several areas. That statement is in accordance to what was observed during the process of development for this CD-ROM - the first volume of the Pedodontics Virtual Library which required the participation of dental and information technology professionals.

The results revealed that $97 \%$ of the interviewees showed interest in the process of development of the CD-ROM.

Some software utilized in this research, such as the Adobe Photoshop 5.0, is available at the Discipline of Pedodontics. It is important to have technical knowledge of that software, and one of the suggestions from the interviewees is the promotion of integration between dentistry and information technology, so that professors and students can benefit from the latter.

The development of the CD-ROM - which is one of the most utilized multimedia products for personal computers - followed the steps proposed by BUGAY (2000). After a subject was selected, a script based on the works of BUSSADORI et al. (2000) was created. Visual and sonorous resources, rather than long texts, were used, in order to achieve the didactic purposes of the material.

As for navigation, $20 \%$ of the interviewees suggested some modifications. These modifications were accepted and introduced in the final CD-ROM, since some links in fact did not allow adequate navigation. According to CARVAlHO JR., SABbatinI (1999), an appropriate navigation system enables interactive - and not linear - access to information, and it is achieved with the aid of special resources (icons, menus and buttons) and free transit through the screens.

Regarding layout and images, only $17 \%$ of the interviewees suggested modifications. Since $83 \%$ had no suggestions, these aspects remained unaltered. As for texts, $30 \%$ suggested changes due to the fact that texts did not fill up the hole screen, notwithstanding that printing was in the ideal size.

Based on the obtained results, it was ascertained that the CD-ROM was well accepted as a teaching and learning method. Aware of the need for constant recycling, the interviewees perceived the importance of that kind of didactic tool, as well as the need for adapting to it, gradually, in order to make it part of the professors' and students' routine.

\section{CONCLUSIONS}

Based on the results, one can conclude that:

- The most utilized didactic tools in class are slides and blackboards. The utilization of CD-ROM is scarce and similar between students and professors.

- Most of the interviewees access the Internet, but few utilize it in distance education

- Around 20\% of the subjects suggested alterations related to the layout, links and images of the program. As for the texts, $30 \%$ would make alterations.

- The CD-ROM was clear as to the presentation of techniques and their indications.

- The interviewees believed the CD-ROM was a good didactic method and showed interest in learning how to create one. It was clear that the CD-ROM was approved as a teaching and learning tool, which makes its application completely feasible and relevant.

\section{RESUMO}

\section{Biblioteca Virtual Odontopediátrica}

Nesta pesquisa, um CD-ROM de Dentística Odontopediátrica foi desenvolvido, originando o primeiro volume da Biblioteca Virtual Odontopediátrica. Estando o CD-ROM pronto, um questionário foi aplicado a 30 entrevistados, compreendendo professores, alunos de pós-graduação e graduação, para avaliação dos métodos de ensino-aprendizagem. As questões sobre o CD-ROM foram a respeito do formato do programa, a clareza das técnicas apresentadas, a facilidade de utilização e o valor do CD-ROM como um método didático. O questionário avaliou características pessoais dos entrevistados também. As respostas foram analisadas descritivamente por meio de tabelas de freqüência e teste exato de Fisher. Após avaliação dos resultados foi possível concluir que os métodos didáticos mais utilizados em classe foram slides e quadro negro, enquanto a utilização do CD-ROM foi incomum para professores e alunos. A maioria dos entrevistados utiliza a Internet e muito poucos têm experiência com educação à distância. O programa é muito claro nas técnicas apresentadas e suas indicações. Os entrevistados consideraram o CD-ROM um bom método didático e demonstraram interesse em aprender como usá-lo. É possível concluir que o CD-ROM interessou o entrevistado, que o achou útil como método de ensino-aprendizagem. 


\section{DESCRITORES}

CD-ROM. Dentística odontopediátrica. Bibliotecas.

\section{BIBLIOGRAPHIC REFERENCES}

BUGAY, E. L. Director. Florianópolis : Bookstore, 2000. 214 p. BUSSADORI, S. K.; IMPARATO, J. C. P.; GUEDES-PINTO, A. C. Dentística Odontopediátrica: técnicas de trabalho e uso de materiais dentários. São Paulo : Santos, 2000. 169 p.

BUSSADORI, S. K. Motivação do paciente infantil através de CD-ROM. J Bras Odontopediatr Odontol Bebê, v. 6, p. 107-110, 1999.

CARVALHOJR., P. M.; SABBATINI, R. M. E. Aplicações da multimídia na Medicina. Rev Informédica, v. 1, n. 6, p. 15-19, 1994. Disponível em: http://home.nib.unicamp.br/ sabbatin.

CHAVES, E. O. C.; SETZER, V. W. O uso de computadores em escolas: fundamentos e críticas. Disponível em: $h t t p: / / w w w . e d u-$ tecnet.com.br.

LÉVY, P. Cibercultura. São Paulo : Editora 34, 1999. 264 p.

LÉVY, P. As tecnologias da inteligência: o futuro do pensamento na era da informática. Rio de Janeiro : Editora 34, 1993. 208 p. MICROSOFT EDUCACIONAL. Distance education by means of the Internet (Ensino à distância usando Internet). Disponível em: http://www.microsoft.com/brasil/educacional.

SETZER, V. W. Computadores na educação: por quê, quando e como. Disponível em: http://www.ime.usp.br/ vwsetzer.

SETZER, V. W. O computador como instrumento de antiarte.

Disponível em: http://www.ime.usp.br/ vwsetzer.

SETZER, V. W. A obsolescência do ensino. Disponível em: http://www.ime.usp.br/ vwsetzer.

TAJRA, S. F. Informática na educação - novas ferramentas pedagógicas para o professor da atualidade. São Paulo : Érica, 1998. $112 \mathrm{p}$

TOFFLER, A.; TOFFLER, H. A terceira onda. Rio de Janeiro : Record, 1997.

YOUSSEF, A. N.; FERNANDES, V. P. Informática e sociedade. São Paulo : Ática, 1988. 64 p.

Aceito para publicação em 11/2003

\section{Reunião da ABENO em Vitória!}

A 39ª Reunião da ABENO será realizada em Vitória, Espírito Santo.

\section{O tema central para a próxima Reunião é: "Ensino e saúde: a integração do ensino para a atenção integral em saúde".}

\section{Compareça!}

Acesse o site http://www.abeno.org.br

para obter informações sobre prazos

para inscrição e apresentação de trabalhos. 